\title{
Epidemiological and Cytological Aspects of Cervical Dystrophies in Senegal Using Cervico-Uterine Smears
}

\author{
Ndiadé $A^{1}$, Diallo $\mathrm{AK}^{4 *}$, Diatta $\mathrm{AL}^{3}$, Senghor $\mathrm{F}^{3}$, Sagna $\mathrm{SD}^{2}$, Thiam $\mathbf{M}^{5}$ and Faye $\mathbf{O}^{2}$ \\ ${ }^{1}$ Laboratory of Clinical Cytology, Cytogenetics, Reproductive Biology and Human Development, HEINRICH LUBCKE Regional
} Hospital of Diourbel, West Africa

${ }^{2}$ Histology-Embryology Laboratory, Department of Biology and Functional Explorations, Faculty of Medicine, Pharmacy and Odontology, Cheikh Anta Diop University, West Africa

${ }^{3}$ Department of Biology and Functional Exploration, FRU of Health Sciences, Assane Seck University of Ziguinchor, West Africa

${ }^{4}$ Regional Hospital of Saint Louis, West Africa

${ }^{5}$ Radiology and medical imaging of national university hospital center of FANN, West Africa

*Corresponding author: Diallo AK, Regional Hospital of Saint Louis, West Africa

\section{ARTICLE INFO}

Received: 蔧October 19, 2021

Published: 慧 October 27, 2021

Citation: Ndiadé A, Diallo AK, Diatta AL, Senghor F, Sagna SD, et al., Epidemiological and Cytological Aspects of Cervical Dystrophies in Senegal Using Cervico-Uterine Smears. Biomed J Sci \& Tech Res 39(4)-2021. BJSTR. MS.ID.006333.

Keywords: Dystrophy; Cervix ; CervicoVaginal Smear

\begin{abstract}
Objectives: To identify the different types of cervical dystrophy in the DAKAR region and make a comparison between the epidemiological and cytological aspects.

Patients and Methods: 2391 cases of significant cervico-uterine smears performed in the period from August 1, 2014 to June 1, 2016. Data collection was performed at the laboratory of Cytology, Cytogenetics and Reproductive Biology of the CHU Aristide Le Dantec.

Results: The average age of the patients was 47.72 years. Patients referred for routine check-ups with no apparent clinical manifestations represented $43.16 \%$. The women with more than 5 children were $8.67 \%$, sometimes with multiple abortions. Infectious dystrophies accounted for $54.37 \%$.
\end{abstract}

Conclusion: Cervical dystrophy are benign lesions that could, by their persistence, lead to low-grade epithelial lesions.

\section{Introduction}

The cervico-uterine smear or cervical smear is a collection of cells from the cervix in order to detect at an early stage any cellular abnormality that may suggest the presence of precancerous or cancerous lesions of the cervix as well as lesions of dystrophy [1]. Dystrophy is an abnormality of cell growth, which is distinct from the metaplastic phenomenon and dysplasia. It consists of mild and limited morphological abnormalities, thought to be of inflammatory or hormonal origin. These abnormalities must be considered according to the context in which they are observed (ectopy metaplasia, atrophy, treatment, irrigative states, and infections) [2].

\section{Methods}

It was a retrospective study from August 1, 2014 to June 1, 2016 carried out at the Aristide LE DANTEC hospital in the laboratory of clinical cytology and reproductive biology. The technique used to detect dystrophy lesions was the cervico-vaginal smear.

\section{Patients}

The study involved 2391 cases of significant cervico-uterine smears in women from various health facilities in the country and sometimes in the sub region. Women in their menstrual period and women in advanced pregnancy were excluded. 


\section{Cervico-uterine Sampling}

The cervico uterine sampling made in the laboratory of clinical cytology and reproductive biology at Aristide LE DANTEC hospital of Dakar was carried out according to the following procedure: registration of the patient on arrival, the patient was registered in a register with an identifying number, second name, first name, age, and origin and billing number. After this step, a receipt with the registration number was given to the patient to be presented on the day the results are to be retrieved; and interrogation was carried out based on the survey form.

\section{Papanicolaou Coloration}

The slides are then dried and stained using the Papanicolaou method.

\section{Interpretation}

Satisfactory smears are smears with an abundant epithelial cell population (covering $20 \%$ of the slide) of intact morphology, corresponding to squamous (ectocervix), glandular (end cervix) or metaplastic cells without inflammatory reaction or excessive bleeding. These are smears that cannot be reliably analyzed for the following reasons: paucicellar swabs; dense inflammatory or hemorrhagic lesions masking the epithelial elements.

\section{Ethical Consideration}

The study protocol was approved by the Ethics Committee of the faculty of medicine, pharmacy and odontology in Cheikh Anta Diop University, Dakar, Senegal. A written informed consent was taken from all participants.

\section{Statistical Analysis}

The data was stored and analyzed on the Excel software.

\section{Results}

\section{Age}

The mean age of the patients was 47.72 years with a standard deviation of 11.37 years. The most represented age (mode) was 40 years (Figure 1).

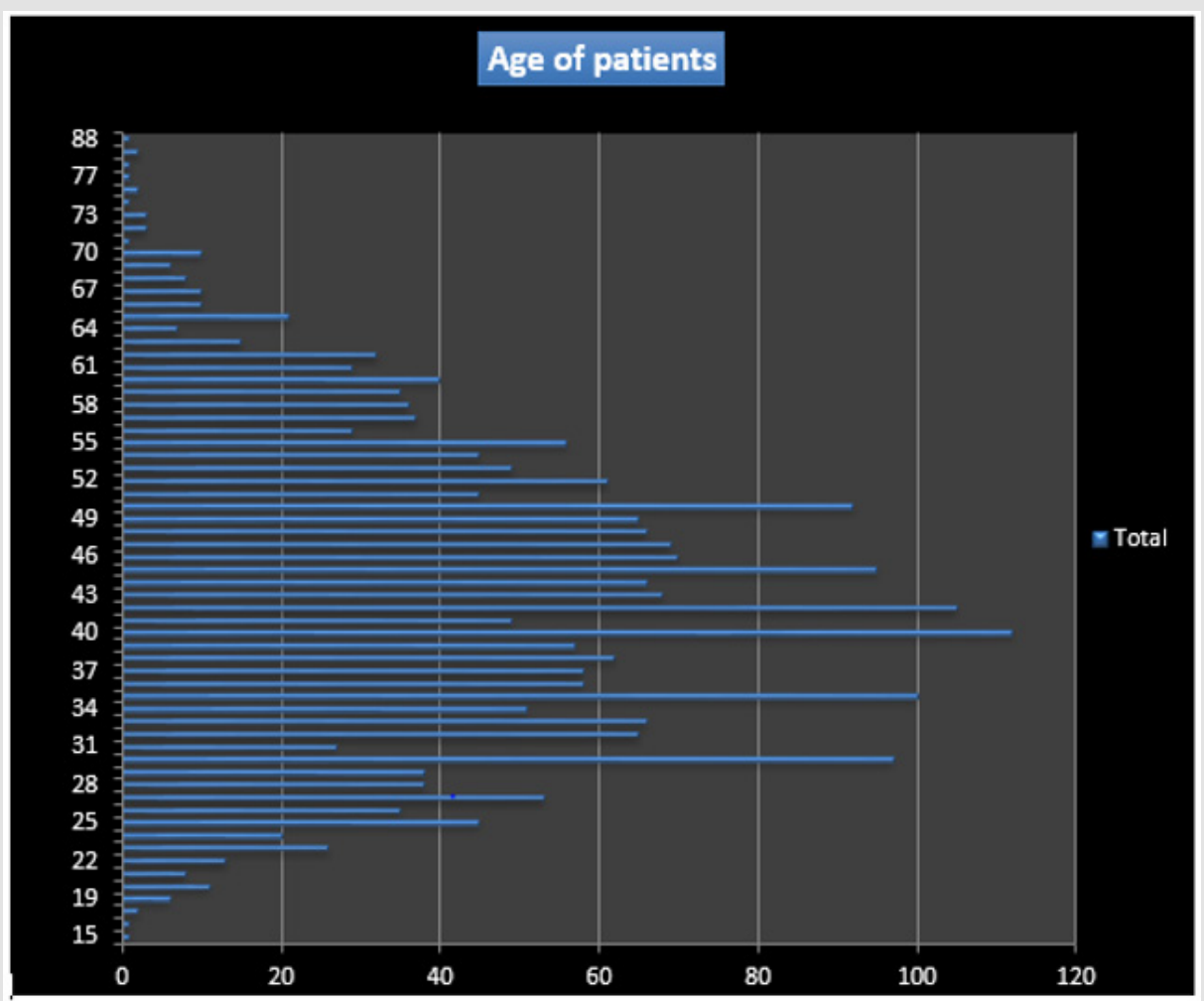

Figure 1.

\section{Reason of Sending}

Routine check-ups with no apparent clinical manifestations represented $43.16 \%$ of patients. The other requests were due to various clinical manifestations: metrorrhagia, primary or secondary amenorrhea, pelvic pain, and dysmenorrhea.

\section{Types of Dystrophies}

Multiple dystrophic lesions (60.85\%) were found of infectious (mild, moderate and intense) and hormonal type. Infectious dystrophies accounted for $54.37 \%$. The infections encountered were bacterial, parasitic (chlamydial), fungal or viral (herpetic) (Table 1). 
Table 1.

\begin{tabular}{|c|c|c|}
\hline Results & N & Rate \\
\hline To be taken over & 1 & $0,04 \%$ \\
\hline Intense hormonal dystrophies & 7 & $13,13 \%$ \\
\hline Mild hormonal dystrophies & 6 & $0,25 \%$ \\
\hline Moderate hormonal dystrophies & 141 & $5,90 \%$ \\
\hline Intense infectious dystrophies & 312 & $13,05 \%$ \\
\hline Mild infectious dystrophies & 127 & $5,31 \%$ \\
\hline Moderate infectious dystrophies & 861 & $36,01 \%$ \\
\hline Others & 936 & $26,31 \%$ \\
\hline Total & 2391 & $100 \%$ \\
\hline
\end{tabular}

\section{Discussion}

\section{Epidemiological Data}

Systematic analysis of the results of our study provided us with important information on the epidemiological data of cervicouterine smears in Senegal. Indeed, after 22 months of collection, the mean age of the patients in our series was 47.72 years with extremes between 15 and 88 years. In Ethiopia, Mesele and his team found the same average age in 2010 (47.7 years), after 6 months of study [3]. This age generally corresponds to the period of genital activity in most women. Epidemiological studies have shown a strong correlation between sexual age and certain HPV infections [4] and patients were sometimes referred by various public (more than $65 \%$ ) and private health facilities. This can be explained by the rather accessible cost of this examination in our center (less than 10 euros) compared to private structures that perform this same examination. Our countries have very little universal health coverage, unlike several countries in the North where adherence to screening is higher but limited in some areas by disparities [5]. Our patients lived mostly on the outskirts of Dakar, $53.47 \%$. The departments of Pikine and Guédiawaye are home to more than $50 \%$ of Dakar's population [6]. We therefore believe that increasing the number of public screening facilities in the Dakar suburbs would surely increase adherence to systematic screening.

Asymptomatic subjects referred for routine screening represented $43, .17 \%$. These results are in contrast to those obtained by Diallo and his team, who showed 20 years ago that in the absence of functional urogenital signs, women rarely consulted Senegalese health facilities for early detection of cervical lesions
[7]. In France, the high health authority recommends systematic screening for precancerous and cancerous cervical lesions by cervico-uterine smears every three years in women aged 25 to 65 [8]. We note that education, information and communication about cervico uterine diseases are fundamental in their prevention.

\section{The Dystrophic Smears}

Dystrophic smears with an inflammatory background were founded in $60.73 \%$ of patients, $54.37 \%$ of which were infectious. Infections are of several types (viral, bacterial, parasitic and mycotic), sometimes intertwined. Cervicitis and cervico-vaginitis are very frequent in developing countries and are characterized by desquamation and ulceration of the surface epithelium with infiltration of neutrophils [9]. A study conducted in the same department found a rate of dystrophy almost similar: $61.33 \%$. The frequency of infections in our countries is explained by several factors including polygamy, poverty and ignorance.

\section{Conclusion}

Cervical dystrophy lesions are benign lesions that could, by their persistence, lead to low-grade epithelial lesions.

\section{References}

1. Abbara A (2021) Frottis cervico utérin, frottis cervico-vaginal.

2. Frappart L (2004) Histopathology and cytopathology of the uterine cervix: Digital atlas. International Agency for Research on Cancer.

3. Mesele B, Fasil T, Hailemariam S, Amare D (2015) Risk factors associated with invasive carcinoma among women attending Jimma University Specialized Hospital, Southwest Ethiopia: A case control study. Ethiop J Health Sci 25( $\left.{ }^{\circ} 4\right)$ : 345-352.

4. Xavier BOSCH (2006) Prevention strategies of cervical cancer in the HPV vaccine era. Gynecologic Oncology 103(1): 21-24.

5. (2014) Haute Autorité de Santé (HAS). Informations biologiques: dépistage et prévention du cancer du col de l'utérus. Feuillets de Biologie. Juillet 5: $\mathrm{N}^{\circ} 319$.

6. Enda graf Sahel (2009) Pikine aujourd'hui et demain: Diagnostic participative de la ville de Pikine, Dakar, Sénégal.Enda sahel et Afrique de l'Ouest. Mai.

7. Enche Razavi F, Escudier E (2008) Embryologie humaine: De la molécule à la Clinique (4 ${ }^{\text {th }}$ Edn.)., Elsevier Masson, pp. 239-253.

8. Rochoy M, Raginel T, Favre J, Soueres E, Messaadi N, et al. (2017) Factors associated with the achievement of cervical smears by general practitioners. BMC research notes 10: 723.

9. Sellors JW, Sankaranarayanan R (2003) Colposcopie et traitement des Néoplasies Cervicales Intraépithéliales: Manuel à usage des debutants. Centre International de Recherche sur le Cancer. Lyon, France, p. 1-155. 
ISSN: 2574-1241

DOI: $10.26717 /$ BJSTR.2021.39.006333

Diallo AK. Biomed J Sci \& Tech Res

(c) (P) This work is licensed under Creative Commons Attribution 4.0 License

Submission Link: https://biomedres.us/submit-manuscript.php

$\begin{array}{ll}\text { BIOMEDICAL } & \text { Assets of Publishing with us } \\ \text { RESEARCHES } & \text { - Global archiving of articles } \\ \text { - Immediate, unrestricted online access }\end{array}$

